\title{
Konkurencja jako narzędzie osiągnięcia zrównoważonego rozwoju w transporcie kolejowym
}

\author{
Competition as a Tool for Achieving Sustainable Development in Rail Transport
}

\author{
Stefan Akira Jarecki \\ Wyższa Szkoła Informatyki Stosowanej i Zarządzania w Warszawie \\ ORCID: https://orcid.org/0000-0002-5738-3036• s.jarecki@wit.edu.pl \\ Zgłoszono: 15.12.2020; zrecenzowano: 18.02.2021; zaakceptowano do druku: 4.03.2021
}

Streszczenie: Koleje mają kluczowe znaczenie dla osiągnięcia zrównoważonego rozwoju transportu. Ustawodawca krajowy i unijny uznali, że ze względów środowiskowych koleje powinny mieć duży udział w przewozach ogółem. Według UE, konkurencja na rynkach przewozów kolejowych zachęci operatorów do lepszego reagowania na potrzeby klientów, poprawy jakości usług i ich efektywności kosztowej, a tym samym wzmocni pozycję konkurencyjną kolei. W związku z tym prawo UE otworzyło rynki przewozów kolejowych na konkurencję. Celem artykułu jest analiza, czy jest to wystarczające do osiągnięcia zrównoważonego rozwoju transportu. Skupiam się na istniejących przepisach prawa, ich doprecyzowaniu (interpretacji) i usystematyzowaniu. Dlatego charakter moich badań jest generalnie dogmatyczny. Moim zdaniem, konkurencja w transporcie kolejowym może przyczynić się do wzrostu przewozów kolejowych, należy jednak zapewnić, aby koszty jej wprowadzenia nie przewyższały korzyści z tego tytułu. Ponadto, do osiągnięcia celów polityki krajowej i unijnej w zakresie zrównoważonego rozwoju transportu niezbędne jest zapewnienie równych warunków konkurencji między koleją a mniej przyjaznymi środowisku rodzajami transportu, w szczególności transportem drogowym (zwłaszcza w zakresie opłat za korzystanie z infrastruktury).

Słowa kluczowe: zrównoważony rozwój transportu, kolej, konkurencja na kolei

\begin{abstract}
Railways are crucial for the achievement of sustainable transport development. National, along with EU legislators, recognised that, for environmental reasons, railways should have a high share in modal split. According to the EU, competition in rail service markets will encourage railway operators to become more responsive to customer needs, improve the quality of their services, and their cost-effectiveness and thus, they will strengthen the competitive position of railways. Therefore, the EU's law duly opened up railway service markets to competition. The aim of this article is to analyse whether it is sufficient to achieve sustainable transport development. I shall focus on the existing law regulations, their clarification (interpretation), and systematisation. Therefore, the character of my research will be generally dogmatic. In my opinion, competition in rail transport can contribute to its increase, however, it should be guaranteed that the costs of introducing competition would not exceed its benefits. Moreover, to achieve the goals of national and EU policy in the area of sustainable transport development, it is necessary to ensure the equal conditions of competition between rail and less environmentally-friendly modes of transport, especially road transport (in particular, with regard to fees for the use of infrastructure).
\end{abstract}

Keywords: sustainable transport development, railway, competition in railways 


\section{Wstęp}

Kolej jest uznawana za jeden z najbardziej przyjaznych środowisku naturalnemu rodzajów transportu. Rozwój tego środka przemieszczania się jest kluczowym warunkiem osiągnięcia zrównoważonego rozwoju transportu. Pod tym pojęciem można rozumieć taki rozwój systemu transportowego, który zaspokaja związane z transportem potrzeby obywateli w sposób, który pozwala na zachowanie zasobów i walorów środowiska w stanie gwarantującym możliwość korzystania z nich zarówno przez obecne, jak i przyszłe pokolenia (Grabowska 2001, 196-197).

W celu zagwarantowania takiego stanu rzeczy konieczne jest zahamowanie ekspansji transportu drogowego i przeniesienie przewozów na bardziej ekologiczne gałęzie transportu, w tym na kolej. Najważniejszym celem unijnej polityki transportowej jest w związku z tym przekierowanie potoków podróżnych i ładunków ze szkodliwych dla środowiska naturalnego rodzajów transportu, głównie transportu drogowego, na kolej. Zgodnie z ambitnymi celami sformułowanymi przez Unię Europejską (UE) w białej księdze pt. Plan utworzenia jednolitego europejskiego obszaru transportu - dażenie do osiagnięcia konkurencyjnego i zasobooszczędnego systemu transportu (Biała księga $\operatorname{COM}(2011) 144)$, do 2030 r. $30 \%$ drogowego transportu towarów na odległościach większych niż $300 \mathrm{~km}$ należy przenieść na inne środki transportu, w szczególności na kolej, natomiast do 2050 r. powinno to być ponad 50\% tego typu transportu. Obecnie w Polsce, w zależności od wskaźnika (tony lub tonokilometry), udział transportu kolejowego w przewozach ogółem kształtuje się na poziomie $11,7^{-12,6 \%}$ i w ostatnich latach spada, podczas gdy udział transportu drogowego rośnie i wynosi 8o,1-85\% (GUS 2018, 16). Zwiększeniu udziału kolei w przewozach ogółem ma służyć wprowadzenie konkurencji w zakresie działalności polegającej na wykonywaniu przewozów kolejowych.

Celem artykułu jest zbadanie, czy wprowadzenie wewnątrzgałęziowej konkurencji w sektorze transportu kolejowego jest wystarczające do osiągnięcia zakładanych celów i gwarantuje zrównoważony rozwój transportu. W mojej opinii, wewnątrzgałęziowa konkurencja jest pożądana, ale nie w każdym przypadku. Jej wprowadzenie zawsze powinno wiązać się ze zbadaniem, czy koszty jej urzeczywistnienia nie będą przewyższać wynikających z tego korzyści. Ponadto, do przekierowania transportu ze szkodliwych dla środowiska rodzajów transportu (w szczególności z transportu drogowego) na kolej niezbędne jest także zapewnienie równych warunków konkurencji międzygałęziowej oraz promowanie transportu kolejowego. W zakresie wykorzystanej metody badawczej należy wskazać, że koncentruje się ona na ustalaniu istniejących przepisów prawa, ich wyjaśnianiu (interpretacji) i systematyzacji. Rozważania prowadzone w niniejszym artykule mają zatem charakter dogmatyczny.

\section{Wartości urzeczywistniane w transporcie kolejowym}

Uregulowania dotyczące funkcjonowania transportu kolejowego są wprowadzane przede wszystkim na poziomie prawa UE. Prawodawca unijny często artykułuje wartości, do urzeczywistnienia których dąży w preambułach do aktów prawnych. Są one również wyrażane w różnego rodzaju dokumentach strategicznych i komunikatach. Jak wskazano w komunikacie Komisji Wspólnotowe wytyczne dotyczace pomocy państwa na rzecz przedsiębiorstw kolejowych (Komunikat 2008, pkt 1), koleje dysponują unikatowymi atutami: jest to środek transportu bezpieczny i niepowodujący zanieczyszczeń. Transport kolejowy może więc w znacznym stopniu przyczynić się do rozwoju zrównoważonego transportu w Europie. W białej księdze Europejska polityka transportowa na 2010 rok: czas decyzji (Biała księga $\operatorname{COM}(2001) 370)$ i jej przeglądzie średniookresowym (Komunikat $\mathrm{COM}(2006) 314$ ) podkreślono ważną rolę dynamicznego sektora kolejowego, który przyczynia się do stworzenia jednolitego i stale rozwijającego się rynku europejskiego, a także do 
ustanowienia wydajnego, bezpiecznego i czystego systemu przewozów towarowych i osobowych. Samolot emituje średnio $268 \mathrm{~g}$ $\mathrm{CO}_{2}$ na pasażerokilometr i przewozi średnio 88 osób, samochód - odpowiednio $104 \mathrm{~g}$ $\mathrm{CO}_{2}$ na pasażerokilometr i 1,5 osoby, autobus - odpowiednio $68 \mathrm{~g} \mathrm{CO}_{2}$ na pasażerokilometr i 68 osób, pociąg zaś emituje średnio zaledwie $14 \mathrm{~g} \mathrm{CO}_{2}$ na pasażerokilometr i przewozi średnio aż 156 osób (Europejska Agencja Środowiskowa 2016). Według danych Fundacji ProKolej, jeden pociąg ma pojemność 15 autobusów i 200 samochodów osobowych. W przewozach towarowych jeden skład zastępuje natomiast 77 ciężarówek. Transport kolejowy pochłania przy tym miej terenu niż transport drogowy (Fundacja ProKolej 2020). Kolej odgrywa również istotną rolę w dostarczeniu społeczeństwu usług publicznych w zakresie przewozów pasażerskich, tj. świadczonych w sposób ciągły i niedyskryminacyjny powszechnie dostępnych usług przewozowych (o bardziej masowym charakterze), które cechują się odpowiednim poziomem bezpieczeństwa, wyższą jakością lub niższą ceną niż usługi świadczone tylko na zasadzie swobodnej gry sił rynkowych.

Transport kolejowy w Europie nie ma jednak dobrego wizerunku. Począwszy od lat sześćdziesiątych do końca dwudziestego wieku transport ten stale podupadał. Przewozy kolejowe, tak towarowe jak i pasażerskie, utraciły na znaczeniu w porównaniu z innymi rodzajami transportu. Udział kolei w przewozach ogółem spadał. Tradycyjne przedsiębiorstwa kolejowe nie były w stanie zaoferować niezawodności i terminowości, których wymagali klienci, co doprowadziło do odejścia od transportu kolejowego na rzecz innych rodzajów transportu, przede wszystkim transportu drogowego. Nawet jeśli kolejowe przewozy pasażerskie w dalszym ciągu rosły w wartościach bezwzględnych, to jednak wzrost ten był ograniczony w porównaniu z przyrostem występującym w transporcie drogowym i lotniczym. Prawodawca unijny upatruje przyczyn tego stanu rzeczy przede wszystkim w braku efektywności sektora i niskiej jakości usług przewozowych. Jednocześnie uznaje, że remedium na te problemy jest rozwój konkurencji w zakresie działalności polegającej na wykonywaniu przewozów kolejowych. Polityka Unii Europejskiej mająca na celu przywrócenie dynamiki sektorowi kolejowemu koncentruje się więc na stopniowym wprowadzaniu warunków umożliwiających powstanie konkurencji na rynkach kolejowych usług transportowych (konkurencja wewnątrzgałęziowa). Unia podejmuje także działania towarzyszące tym inicjatywom, takie jak wspieranie normalizacji i harmonizacji technicznej na poziomie europejskich sieci kolejowych w celu osiągnięcia ich pełnej interoperacyjności (Komunikat 2008, pkt 2-8).

\section{Konkurencja w transporcie kolejowym}

W sektorze transportu kolejowego wyróżnia się dwa zasadnicze modele konkurencji, tzw. model konkurencji na rynku (competition in the market) oraz tzw. model konkurencji o rynek (competition for the market). Pod pojęciem modelu konkurencji na rynku rozumnie się sytuację, w której poszczególne przedsiębiorstwa kolejowe konkurują między sobą w zakresie świadczonych usług przewozowych o pasażerów w przewozach osób oraz o nadawców ładunków w przewozach towarów. Model konkurencji o rynek to z kolei system organizacji rynku transportu kolejowego, w którym konkurencja pojawia się na etapie wyboru przedsiębiorstw świadczących usługi przewozowe, lecz nie występuje na etapie ich świadczenia. W tym modelu władze publiczne wybierają w drodze konkurencyjnej i niedyskryminacyjnej procedury (zazwyczaj w drodze przetargu), na określony czas przedsiębiorstwa świadczące usługi na danym obszarze. $\mathrm{Na}$ etapie świadczenia usług przewozowych konkurencja między przedsiębiorstwami świadczącymi usługi jest jednak wyłączona. Przedsiębiorstwa kolejowe wybrane do realizacji usług otrzymują de facto monopol na przewozy na wskazanym obszarze w ściśle określonym przedziale czasu (Antonowicz 2008, 40; OECD 2005, 8). 
Początkowo prawodawca unijny skupiał się na wprowadzaniu konkurencji określanej jako model konkurencji na rynku. Zagwarantowano zatem wszystkim zainteresowanym przedsiębiorstwom kolejowym (przewoźnikom) równy i niedyskryminacyjny dostęp do sieci kolejowej (liniowej infrastruktury kolejowej, w pewnym uproszczeniu - torów kolejowych), w ranach tzw. zasady dostępu stron trzecich do infrastruktury kolejowej (TPA - Third Party Access). Wprowadzono także inne rozwiązania służące realizacji tego celu, takie jak unbundling. Polega ono na rozdzieleniu działalności w zakresie zarządzania infrastrukturą kolejową i świadczeniu przewozów z jej wykorzystaniem. Separacja infrastruktury i działalności usługowej znacząco ułatwia zapewnienie niedyskryminacyjnego dostępu do infrastruktury kolejowej. Rozwiązanie takie zapobiega naturalnemu dążeniu przedsiębiorstwa kolejowego, jednocześnie posiadającego infrastrukturę i realizującego przewozy (przedsiębiorstwo pionowo zintegrowane), do blokowania dostępu do niej konkurentom (Szydło 2005, 257; Antonowicz 2008, 41; Szydło 2010a, 115). Podjęcie tych działań umożliwiło zaistnienie konkurencji w sektorze transportu kolejowego, zwłaszcza w zakresie przewozów towarowych, nie doprowadziło jednak do pełnego jej rozwoju. W szczególności konkurencja nie rozwinęła się w odniesieniu do przewozów pasażerskich.

Zdecydowana większość pasażerskich przewozów kolejowych w państwach europejskich (nie inaczej jest w Polsce) ma charakter usług publicznych. Świadczenie odpowiedniej jakości tych przewozów przy jednoczesnym zachowaniu ich powszechnej dostępności, tj. akceptowalnego społecznie poziomu cen biletów, jest co do zasady nierentowne. Są one więc organizowane i finansowane przez władze publiczne. Właściwi w tym zakresie są tzw. organizatorzy publicznego transportu zbiorowego, tj. organy administracji publicznej powierzające wykonywanie przewozów (zarówno szczebla samorządowego, jak i rządowego). Przewozy komercyjne stanowią jedynie uzupełnienie przewozów o charakterze służby publicznej.

Nierentowny charakter przewozów kolejowych stanowiących usługi publiczne skutkuje tym, że mogą być wykonywane na danym obszarze w tym samym czasie zasadniczo tylko przez jednego operatora. Powierzenie takich przewozów na tych samych trasach kilku podmiotom, które konkurowałyby ze sobą, skutkowałoby wzrostem kosztów wykonywania usług, a także zmniejszeniem przychodów każdego z nich. Konsekwencją takiego stanu rzeczy byłoby zwiększenie zapotrzebowania na publiczne finansowanie. Rozwiązanie takie mogłoby także wiązać się z uciążliwościami dla pasażerów (problemy z konstruowaniem rozkładu jazdy i zachowaniem cykliczności połączeń ${ }^{1}$ ) i większym obciążeniem aparatu administracyjnego (konieczność sprawowania nadzoru nad realizacją usług przez kilku, a nie przez jednego operatora). Nie byłoby więc ono ani racjonalne, ani ekonomicznie uzasadnione. $\mathrm{Z}$ tego powodu $\mathrm{w}$ zakresie większości przewozów pasażerskich nie jest możliwe wprowadzenie typowej konkurencji, konkurencji na rynku, w przypadku której w tym samym czasie na rynku działa wielu przedsiębiorców współzawodniczących między sobą o klientów (pasażerów) przede wszystkim ceną i jakością usług. W przewozach pasażerskich taki model konkurencji może zaistnieć raczej w wąskim zakresie, tylko w odniesieniu do przewozów kolejowych, które mogą być świadczone na zasadach komercyjnych (tj. bez finansowej interwencji państwa). Z powyższych względów konkurencję w zakresie przewozów kolejowych stanowiących usługi publiczne wprowadza się w inny sposób. Wykorzystuje się w tym przypadku opisany powyżej model konkurencji o rynek polegający na

\footnotetext{
Na przykład w Austrii konkurencja na rynku doprowadziła do zakłócenia funkcjonowania tzw. Zintegrowanego Cyklicznego Rozkładu Jazdy (Integrated Periodic Timetable). Zaletą tego rozkładu jest zapewnienie dogodnego (bez długiego czasu oczekiwania) skomunikowania pociągów lokalnych i regionalnych z dalekobieżnymi (Smoliner 2019).
} 
wyłanianiu w procedurze konkurencyjnej operatora świadczącego usługi publiczne na ograniczony okres. W stosunkowo małym zakresie, niejako pomocniczo, w odniesieniu do niewielkiej części tych przewozów, która może być realizowana na zasadach komercyjnych, w formule konkurencji na rynku.

\section{Konieczność stosowania skomplikowanych rozwiązań prokonkurencyjnych}

Z czasem prawodawca unijny zaczął wyraźnie dostrzegać, że samo zagwarantowanie równego i niedyskryminacyjnego dostępu do infrastruktury kolejowej nie jest wystarczające dla urzeczywistnienia konkurencji w zakresie działalności polegającej na wykonywaniu przewozów kolejowych. W transporcie kolejowym występują bowiem także inne bariery wejścia na rynek, które mają charakter podobny do infrastruktury kolejowej (w tym sensie, że ich istnienie w zbliżony sposób ogranicza możliwość funkcjonowania konkurencji). Barierami wejścia na rynek określa się czynniki uniemożliwiające lub też przynajmniej istotnie utrudniające przedsiębiorcom wejście na dany rynek i skuteczne konkurowanie $\mathrm{z}$ innymi przedsiębiorcami. Czynniki te mogą mieć charakter prawny bądź ekonomiczny (Szydło 2010b, 70-71). W przypadku każdego rynku występują jakieś bariery wejścia. Problem zaczyna się wówczas, gdy są one na tyle istotne, że de facto uniemożliwiają wejście na rynek nowych podmiotów, chroniąc tym samym działających na nim przedsiębiorców (zazwyczaj zasiedziałych) przed rozwojem konkurencji. Barierami takimi są określone czynniki produkcji, do których trzeba mieć dostęp, by prowadzić działalność na rynku transportu kolejowego i podjąć konkurencję z już funkcjonującymi na nim przedsiębiorstwami, zwłaszcza zasiedziałymi.

Można zidentyfikować następujące czynniki produkcji mające charakter takich barier: infrastruktura usługowa i świadczone za jej pomocą usługi (np. zaplecza techniczne niezbędne do bieżącego utrzymania taboru kolejowego), tabor kolejowy, zasoby ludzkie (pracownicy) oraz informacje o sposobie prowadzenia działalności gospodarczej. Czynnikami tymi dysponują często wyłącznie zasiedziałe przedsiębiorstwa kolejowe, nierzadko są one co najmniej trudne do zduplikowania. Jednocześnie, nawet jeśli ich zduplikowanie jest możliwe, to może być ono niewykonalne w czasie umożliwiającym rozpoczęcie wykonywania usług przewozowych zgodnie z zasadami określonymi przez organizatora odpowiedzialnego za powierzanie i finansowanie danych usług przewozowych. Wydatki na takie czynniki produkcji mogą się również okazać zbyt ryzykowne. Potencjalni operatorzy mogą nie być zainteresowani dokonywaniem kosztownych inwestycji, nie będąc pewni, że zostaną wybrani do wykonywania usług przez ich organizatora, lub mając przed sobą ograniczoną czasowo perspektywę ich świadczenia (nierzadko kilkuletnią, podczas gdy inwestycje w aktywa niezbędne do realizacji kolejowych usług przewozowych często zwracają się po kilkudziesięciu latach). Wiele z tych barier, co wynika z już przedstawionych spostrzeżeń, dotyczy w szczególny sposób przewozów pasażerskich i możliwości funkcjonowania modelu konkurencji o rynek.

Z omówionych względów pełnemu wprowadzeniu konkurencji w sektorze transportu kolejowego muszą towarzyszyć rozwiązania niwelujące znaczenie wskazanych barier wejścia na rynek transportu kolejowego i wyjścia z niego. Rozwiązania takie, wprowadzane w ostatnim czasie przez prawodawcę unijnego, nazywam dezintegracyjnymi (Jarecki 2019, 49-6o). Polegają one na specyficznym określeniu warunków prowadzenia działalności gospodarczej w sektorze transportu kolejowego w taki sposób, by związek pomiędzy czynnikami produkcji, które stanowią szczególną barierę wejścia na rynki przewozów kolejowych i wyjścia $\mathrm{z}$ nich, a przedsiębiorstwami prowadzącymi działalność na tych rynkach uległ rozluźnieniu (osłabieniu). Dzieje się tak, gdy czynniki te są dostępne dla wielu podmiotów funkcjonujących na rynkach przewozów kolejowych lub, co prawda, mogą być wykorzystywane 
w danym okresie tylko przez jedno przedsiębiorstwo, lecz podlegają swobodnemu transferowaniu (przekazywaniu) pomiędzy operatorami kolejno wykonującymi daną usługę (w sensie używania danych czynników produkcji). W efekcie rozwiązania dezintegracyjne powinny uniemożliwić lub ograniczyć możliwość wykorzystywania znaczącej pozycji rynkowej przez niektórych uczestników rynku transportu kolejowego w antykonkurencyjny sposób.

Rozwiązania dezintegracyjne mają różny charakter, pod względem jednak celu ich zastosowania są jednolite. Podstawowym takim rozwiązaniem wprowadzonym $\mathrm{w}$ obszarze infrastruktury usługowej jest zastosowanie zasady dostępu stron trzecich do tego typu obiektów oraz rozdzielenie działalności polegającej na zarządzaniu obiektami infrastruktury usługowej od działalności przewozowej, tj. wdrożenie tzw. unbundlingu. W przypadku taboru kolejowego na organizatorów zamierzających wybrać operatora przewozów kolejowych o charakterze służby publicznej w procedurze konkurencyjnej nałożono obowiązek przeprowadzenia analizy konieczności zastosowania środków dotyczących zapewnienia operatorom skutecznego i niedyskryminacyjnego dostępu do taboru kolejowego. Ponadto przewidziano możliwość wprowadzenia przez nich takich środków, wskazując jednocześnie, jakie rozwiązania mogą oni w tym zakresie zastosować. W odniesieniu do pracowników wprowadzono rozwiązania służące m.in. zapewnieniu sprawnego przejścia pracowników pomiędzy operatorami w przypadku ich zmiany. Polegają one w szczególności na możliwości zastosowania przepisów dyrektywy UE dotyczącej ochrony praw pracowniczych (przejścia pracowników) w przypadku przejęcia przedsiębiorstwa (Dyrektywa 2001/23/WE) także w innych przypadkach niż wprost przez nią przewidziane, tj. na możliwości nałożenia przez organizatorów usług przewozowych na operatorów obowiązku przejęcia pracowników zatrudnionych przez przedsiębiorstwo poprzednio wykonujące przewozy, przy jednoczesnym zagwarantowaniu im dotychczasowych warunków pracy i płacy. Wprowadzono także obowiązek przekazywania potencjalnym nowym operatorom określonych informacji (np. dotyczących popytu ze strony podróżnych, cen biletów, kosztów i przychodów związanych z publicznym transportem pasażerskim, czy specyfikacji infrastruktury i taboru).

Analizowane rozwiązania w znaczący sposób ingerują w prawo własności. Są skomplikowane, ich wprowadzenie wymaga wiedzy eksperckiej, w tym korzystania z doradztwa wyspecjalizowanych w tym zakresie podmiotów. Wiążą się one z dużymi obciążeniami administracyjnymi. Często wymagają wprowadzenia zmian organizacyjnych. Są zatem również kosztowne tak dla przedsiębiorstw kolejowych, jak i władz publicznych (w szczególności organizatorów publicznego transportu zbiorowego). Należy zatem uznać, że zastosowanie zmian jest uzasadnione w takim zakresie, w jakim korzyści z tego tytułu (rozwoju konkurencji), w szczególności dla osiągnięcia zrównoważonego rozwoju transportu, przewyższają koszty z tego wynikające.

\section{Fałszywe przekonanie o zbawiennym wpływie konkurencji wewnątrzgałęziowej}

Konkurencja wewnątrzgałęziowa jest istotna dla realizacji środowiskowych celów Unii Europejskiej. Poprawa jakości usług i efektywności kolei może przyciągnąć nowych klientów do tego rodzaju transportu. Nie należy jednak zapominać o konkurencji międzygałęziowej, w szczególności z transportem drogowym, z którego to - zgodnie z założeniami - mają być przenoszone potoki ładunków i podróżnych na kolej. Tymczasem pozycja konkurencyjna transportu drogowego i kolejowego wyraźnie nie jest równa. Widoczne to jest chociażby w zakresie kosztów korzystania z infrastruktury. $\mathrm{Z}$ danych fundacji ProKolej (Fundacja ProKolej 2020) wynika, że przeważająca część infrastruktury drogowej jest udostępniana nieodpłatnie, podczas gdy korzystanie 
z infrastruktury kolejowej w każdym przypadku wymaga poniesienia wysokich kosztów (całość infrastruktury kolejowej jest udostępniana za opłatą).

O pozycji konkurencyjnej poszczególnych środków transportu decyduje cena przewozu, jakość usługi oraz czas przejazdu. Dla nadawców ładunków w zdecydowanej większości przypadków liczy się przede wszystkim cena przewozu, a nie czas przejazdu. Cena usługi ma zatem kluczowe znaczenie dla pozycji konkurencyjnej kolejowego transportu towarowego. Ta zaś w istotnej mierze zależy od kosztów korzystania z infrastruktury kolejowej. W Niemczech stanowią one na przykład ok. 13\% całkowitych kosztów prowadzenia działalności w zakresie towarowych przewozów kolejowych (Decyzja SA.51956, pkt 16). Opłaty za dostęp do infrastruktury kolejowej w Polsce wciąż należą do jednych z wyższych w Europie. Jak wynika ze sprawozdania specjalnego Europejskiego Trybunału Obrachunkowego (Raport 2016), wyższe opłaty występują tylko w Austrii, Czechach, Irlandii, Estonii, Rumunii, na Litwie, Łotwie oraz na Węgrzech. Dodatkowo, opłata za korzystanie z infrastruktury drogowej przez samochody ciężarowe w Polsce w przeliczeniu na tonokilometr jest niższa niż średnia wysokość opłaty za dostęp do infrastruktury kolejowej. Co więcej, obowiązuje ona tylko na pewnych odcinkach dróg (ok. 15\% sieci drogowej) (Raport 2016, 46).

Najprostszym rozwiązaniem wskazanego problemu byłoby zapewne wyrównanie, za pomocą odpowiednich rozwiązań prawnych, warunków prowadzenia działalności w transporcie drogowym i kolejowym. Uczynienie zbliżonymi kosztów prowadzenia obu rodzajów działalności. Przynajmniej w takim zakresie, w jakim jest to usprawiedliwione. Wydaje się to jednak trudne do zaakceptowania z politycznego punktu widzenia. Rozwiązanie takie wiązałoby się bowiem nieuchronnie ze znacznym wzrostem kosztów transportu drogowego. Innym, możliwym rozwiązaniem jest udzielenie wsparcia finansowego dla przedsiębiorstw kolejowych poprawiającego pozycję konkurencyjną sektora transportu kolejowego względem transportu drogowego. Taką drogą podążyła niedawno Republika Federalna Niemiec (Decyzja SA.51956) oraz Królestwo Niderlandów (Decyzja SA.52898). Oba kraje udzieliły sektorowi kolejowemu wsparcia na obniżenie opłat za dostęp do infrastruktury kolejowej. Rozwiązanie takie trudno jednak uznać za najbardziej sprawiedliwe, optymalne ekonomicznie i korzystne dla podatników, a tym samym najlepsze z punktu widzenia zrównoważonego rozwoju transportu. Niweluje ono bowiem skutki, a nie źródło problemu. Ponadto, różnice w wysokości opłat za dostęp do infrastruktury, choć stanowią jaskrawy przykład nierównego traktowania transportu kolejowego i drogowego, to nie są jedynym źródłem nierówności w tym zakresie. Można bowiem wskazać na ogromne różnice dotyczące obciążeń regulacyjnych i administracyjnych (np. związanych z zapewnieniem bezpieczeństwa transportu). Rozwiązanie tych problemów wymaga usprawnienia zarządzania infrastrukturą kolejową, w tym poprawy efektywności jej eksploatacji. Zasadne jest dokonanie przeglądu barier administracyjnych występujących w transporcie kolejowym i wyeliminowanie zbędnych obciążeń. Ponadto, rozważenia wymaga udzielenie większego wsparcia w niektórych obszarach sektora transportu kolejowego, np. określonym rodzajom transportu towarowego (takim jak transport intermodalny i rozproszony), czy przedsiębiorcom zainteresowanym korzystaniem z transportu kolejowego, w szczególności wesprzeć utworzenie i eksploatację bocznic kolejowych i towarzyszącej im infrastruktury (koszty budowy i utrzymania takiej infrastruktury stanowią poważną barierę $\mathrm{w}$ przejściu $\mathrm{z}$ transportu drogowego na transport kolejowy).

\section{Wnioski}

Warunkiem osiągnięcia zrównoważonego rozwoju transportu jest przeniesienie podróżnych i ładunków ze szkodliwych rodzajów transportu, zwłaszcza z transportu 
drogowego, na kolej. Wprowadzenie konkurencji w zakresie działalności polegającej na wykonywaniu przewozów kolejowych jest pożądane. Może ono bowiem poprawić efektywność przedsiębiorstw kolejowych i jakość świadczonych przez nich usług, co powinno przyciągnąć do kolei nowych klientów. Należy jednak zadbać o to, by koszty urzeczywistnienia konkurencji wewnątrzgałęziowej nie przewyższały korzyści z niej wynikających. Ponadto, chociaż konkurencja wewnątrzgałęziowa przyczynia się do poprawy pozycji transportu kolejowego, to jest zdecydowanie niewystarczająca do zrealizowania zakładanych celów. Osiągnięcie wzrostu udziału transportu kolejowego w przewozach ogółem wymaga również zapewnienia równych warunków konkurencji międzygałęziowej, w szczególności z transportem drogowym, a także wprowadzenia rozwiązań promujących transport kolejowy. Szczególne znaczenie ma w tym względzie zróżnicowanie opłat za korzystanie $\mathrm{z}$ infrastruktury ponoszonych przez różne rodzaje transportu. Nie należy jednak zapominać przy tym o innych rodzajach obciążeń, zwłaszcza o charakterze regulacyjnym, a także konieczności udzielenia odpowiedniego wsparcia w niektórych obszarach sektora transportu kolejowego.

\section{Bibliografia}

Antonowicz, Mirosław. 2008. „Strategia regulacyjna dla rynku transportu kolejowego.” Problemy Zarządzania 6(1): 38-54.

Biała księga COM(2001)370 - Biała księga UE Europejska polityka transportowa na 2010 rok: czas decyzji, COM(2001)370.

Biała księga COM(2011)144 - Biała księga UE Plan utworzenia jednolitego europejskiego obszaru transportu - dążenie do osiągnięcia konkurencyjnego i zasobooszczędnego systemu transportu, $\operatorname{COM}(2011) 144$.

Decyzja SA.51956 - Decyzja Komisji Europejskiej z 10 grudnia 2018 r. w sprawie pomocy państwa SA.51956 (2018/N) - Niemcy - Aid scheme for the promotion of rail freight transport.

Decyzja SA.52898 - Decyzja Komisji Europejskiej z 8 lipca 2019 r. w sprawie pomocy państwa SA.52898
(2019/N) - Królestwo Niderlandów - Financial measure to stimulate rail freight.

Dyrektywa 2001/23/WE - Dyrektywa Rady 2001/23/ WE z 12 marca 2001 r. w sprawie zbliżania ustawodawstw Państw Członkowskich odnoszących się do ochrony praw pracowniczych w przypadku przejęcia przedsiębiorstw, zakładów lub części przedsiębiorstw lub zakładów (Dz. Urz. UE 2001 L 82/16 z późn. zm., polskie wydanie specjalne: rozdz. 5, t. 4, s. 98-103).

Europejska Agencja Środowiskowa. 2016. Emisje dwutlenku wegla z transportu pasażerskiego. Dostęp: 12.12.2020. https://www.eea. europa.eu/pl/pressroom/infografika/emisje-dwutlenku-wegla-z-transportu-pasazerskiego/ view.

Fundacja ProKolej. 2020. Infografiki. Dostęp: 12.12.2020. http://www.prokolej.org/pl/infografiki. Grabowska, Genowefa. 2001. Europejskie prawo środowiska. Warszawa: Wydawnictwo Prawnicze PWN.

GUS (Główny Urząd Statystyczny). 2018. Transportwyniki działalności w 2017 r. Warszawa-Szczecin: Główny Urząd Statystyczny.

Jarecki, Stefan Akira. 2019. Dezintegracja jako narzędzie regulacji rynku transportu kolejowego. Warszawa: EuroPrawo.

Komunikat 2008 - Komunikat Komisji Wspólnotowe wytyczne dotyczace pomocy państwa na rzecz przedsiębiorstw kolejowych (Dz. Urz. UE 2008 C 184/13).

Komunikat COM(2006)314 - Komunikat Komisji Utrzymać Europę w ruchu - zrównoważona mobilność dla naszego kontynentu. Przeglad średniookresowy Białej Księgi Komisji Europejskiej dotyczacej transportu, COM(2006)314.

OECD. 2005. Structural Reform in the Rail Industry. Accessed December 12, 2020. http://www.oecd. org/regreform/sectors/35911008.pdf.

Raport 2016 - Sprawozdanie specjalne. Kolejowy transport towarowy w UE: wciąż nie na wtaściwym torze. Europejski Trybunał Obrachunkowy. 2016. Dostęp: 12.12.2020. https://www. eca.europa.eu/Lists/ECADocuments/SR16_08/ SR_RAIL_FREIGHT_PL.pdf.

Smoliner. Martin. 2019. System train paths as the key to efficient infrastructure usage for on-track competition in ITF-regime. Accessed June 26, 2019. 
http://www.itregep.cz/media/5433917/smoliner. Szydło, Marek. 2010a. Prawo konkurencji a regulacja pdf. sektorowa. Warszawa: Wolters Kluwer.

Szydło, Marek. 2005. Regulacja sektorów infrastrukturalnych jako rodzaj funkcji państwa wobec gospSzydło, Marek. 2010b. Nadużywanie pozycji dominujacej w prawie konkurencji. Warszawa: Wolters odarki. Warszawa: Prawo i Praktyka Gospodarcza. Kluwer. 